\title{
Genetic diversity and differentiation of Chilean plantations of Pinus radiata D. Don using microsatellite DNA markers
}

\author{
By S. EsPinozA ${ }^{1), *}$, C. R. MAGNi ${ }^{2)}$, V. MARTíneZ ${ }^{3)}$, W. GAPARE ${ }^{4)}$ and C. Cordero ${ }^{5)}$
}

(Received 23 ${ }^{\text {th }}$ August 2011)

\begin{abstract}
Radiata pine (Pinus radiata D. Don) is the most important tree species in Chilean forest economy that was introduced to the country in 1892. Despite its economical end ecological relevance, no information about its genetic diversity is today available. Forty individuals of $P$. radiata, representing all populations in the Chilean radiata pine breeding program were genotyped with five microsatellite loci in order to determine genetic diversity and structure of Chilean plantations. The results of genetic diversity indicated that, after its introduction and mass planting, Chilean plantations of $P$. radiata has retained levels of genetic diversity similar to those of the natural populations of the species $\left(\mathrm{H}_{\mathrm{E}}=0.87, \mathrm{~A}=11.4\right)$. Genetic differentiation among populations $\left(\mathrm{F}_{\mathrm{ST}}=0.04\right)$ was low, which means that the genetic variation present in radiata pine in Chile is partitioned among populations, indicating they are poorly differentiated. The structure analysis indicated the genetic base of the present plantations in Chile comes only from one provenance of the native populations. The genetic information provided important implications for the future breeding programs of $P$. radiata in Chile.
\end{abstract}

Key words: Radiata pine, Chilean plantations, genetic diversity, population structure, molecular markers.

\section{Introduction}

Assessment of genetic variation in plant populations has many potential uses. Knowledge of genetic variation within a species can help plant breeders to collect and utilize different genetic resources and predict potential genetic gain in breeding programs (Wu et al., 1999). Reliable information on the distribution of genetic diversity is a prerequisite for sound selection, breeding and conservation programs for forest trees. It is assumed that genetic diversity is of prime importance for species persistence (FRANKEL, 1983; ALLENDORF and LEARY, 1986; GEBUREK, 1997) and is associated with the adaptive and evolutionary potential of populations (ENNOS et al.,

1) Centro de Desarrollo para el Secano Interior, Universidad Católica del Maule, San Miguel Ave 3605, Talca, Chile.

E-Mail: espinoza@ucm.cl

2) Facultad de Ciencias Forestales y de la Conservación de la Naturaleza, Universidad de Chile, Santa Rosa Ave 11315, Santiago, Chile. E-Mail: crmagni@uchile.cl

3) Facultad de Ciencias Veterinarias y Pecuarias, Universidad de Chile, Santa Rosa Ave 11315, Santiago, Chile.

E-Mail: vmartine@uchile.cl

4) CSIRO Plant Industry, GPO Box 1600 ACT 2601, Canberra, Australia. E-Mail: washington.gapare@csiro.au

5) Laboratorio de Biotecnología, Universidad Católica del Maule, San Miguel Ave 3605, Talca, Chile. E-Mail: lcordero@ucm.cl

*) Corresponding author: SERgio Espinoza. Centro de Desarrollo para el Secano Interior, Universidad Católica del Maule, San Miguel Ave 3605, Talca, Chile. Phone: +56071203512. E-Mail: espinoza@ucm.cl
1997). Currently there is an urgent need to determine the adaptive potential of forest trees given their importance in ecosystem functioning and the associated ecological and economic services they provide. One important step to do this is by examining genetic diversity, with microsatellites being the marker of choice in the last years, because they provide useful information on historical demography and population evolution. Microsatellites are also a useful tool to determine adaptability of a species, because they allow estimating effective population size, which in turn reflects fitness and adaptability of a species to new environments (WANG, 2005).

Pinus radiata (D. Don), the predominant plantation softwood species in the southern hemisphere, is native to the California coast (Año Nuevo, Monterey and Cambria) and two offshore islands (Guadalupe and Cedros). Owing to its rapid growth and favorable characteristics for timber production, the species has been widely introduced in Argentina, Australia, China, Spain, Great Britain, Ireland, Italy, New Zealand, South Africa, Turkey and Chile. In Chile radiata pine is the most important exotic forest species, being the most extensively planted conifer in the country (1.46 million ha), comprising 75 percent of the Chilean forest industry base and earning foreign currency on the order of US\$ 5,000 millions in exports (INFOR, 2010). The earliest records show radiata pine was introduced in Chile with only one consignment at least as early as 1890 (LEWIS and Ferguson, 1993; CAMus, 2006), however, information about where the species come from its native range is no available. Also no new introductions until the beginning of genetic improvement programs in the 1980s are registered. At present the species has gone through two generations of selection and breeding for growth, stem form and wood quality traits (BURDON, 1978; FundaCión CHILE, 2005; MuÑoz, 2008), however, despite its economic importance in the country, only limited information is correctly available on the genetic diversity and the effects of the introduction, selection, breeding and subsequent mass plantings after two generations, over the maintenance or loss of its genetic diversity.

In natural and introduced populations of radiata pine moderate to high levels of genetic variability at isozyme, RAPD and microsatellite loci have been reported, with lowest values for isozyme $\left(\mathrm{H}_{\mathrm{E}}=0.095, \mathrm{~A}=1.56\right.$, $\left.\mathrm{F}_{\mathrm{ST}}=0.06\right)$ and highest values for microsatellites $\left(\mathrm{H}_{\mathrm{E}}=0.78, \mathrm{~A}=11, \mathrm{~F}_{\mathrm{ST}}=0.14\right)$ (MoRAN and BELL, 1987; Moran et al., 1988; SMith and Devey, 1994; Aragonés et al., 1997; DEVEY et al., 2002; BELL et al., 2004; KARHU et al., 2006). In Australia, although the original genetic base of the breeding populations may have been of the 
order of 200-300 seed trees from a smaller part of the natural range of radiata pine (Wu et al., 2007), significant genetic gains for growth traits have been realized over two generations of selection and breeding (MATHESON et al., 1986; WU et al., 2007) and levels of genetic diversity, measured with microsatellites, are similar to those of native populations (i.e. $\mathrm{H}_{\mathrm{E}}=0.78$ for Australian plantations and 0.77 for native populations) (DEVEY et al., 2002; BELL et al., 2004; KARHU et al., 2006). According to ADAms (1981) and SzMIDT and Muona (1985) the loss of genetic diversity in gymnosperms during the process of domestication has been relatively minor. In Chile use of genetic diversity in radiata pine focuses largely on genetic improvement programs, which have been aimed primarily to growth and from traits. In recent years wood traits have become relevant due to its impact on the forestry industry (BURDON, 1978; FUNDACIÓN CHILE, 2005; MuÑOZ, 2008). In the 1970's structured breeding programs commenced in the country and eventually the issue of the genetic base was raised. Currently only a limited study using RAPD markers (Random Amplified Polymorphic DNA) on four families reported levels of genetic diversity for the species $\left(\mathrm{H}_{\mathrm{T}}=0.36, \mathrm{~F}_{\mathrm{ST}}=0.04\right)$ (CAMPos et al., 2001). As the radiata pine breeding program in Chile advances to third generation selections, it is important to examine the level of genetic diversity in the breeding populations in order to determine whether there are high levels of genetic diversity to cope with future environmental changes and possible infusions to increase genetic diversity. For this, we used microsatellite markers to estimate the current level of genetic diversity in radiata pine plantations in Chile. Microsatellite markers exhibit codominance and are usually highly polymorphic, and thus, seem to be the ideal marker. Thus, the main goal of the study were (1) to ascertain the levels of genetic variation of radiata pine plantations in Chile, and (2) to determine the genetic differentiation across sites where the species is currently planted in the country.

\section{Material and Methods}

\section{Genetic material}

The material used in this study consisted of a subset of the first generation open-pollinated individuals of the radiata pine breeding program. Individuals were chosen to represent the most widely used in the Chilean breeding program. A total of 40 unrelated individuals, representing different families, were randomly selected from Forestal Celco S.A. and Forestal Mininco S.A. seed orchards. All trees in these seed orchards were selected for superior growth, stem form and volume, and were collected between 1976-1978 in five different sites in Central Chile. We used unimproved seeds stored since the 1970s, which means that individuals used here had not been selected for breeding purposes yet. One seedling per family was used, and families were grouped according to the area of location of plus trees in Eight Region Sandy Soils sites, Seventh Region Coastal sites, Eight Region Coastal sites and Other Areas of the Eight Region (Table 1, Figure 1).

\section{DNA Extraction}

For DNA extraction, seeds from 40 unrelated individuals were grown in the nursery for eight weeks under normal nursery conditions. The seeds were sown on $140 \mathrm{~cm}^{3}$ pots filled with a mixture of composted bark of radiata pine and perlite $(8: 2 \mathrm{v})$, combined with the slowrelease fertilizer Basacote ${ }^{\mathrm{TM}}$ plus $6 \mathrm{M}$. Nine to 14 individuals per plus trees-origin were randomly chosen and Genomic DNA was extracted from needles as described in DNeasy ${ }^{\circledR}$ Plant Handbook (Qiagen).

\section{PCR amplification for microsatellite markers}

Five microsatellites that were previously used for DNA fingerprinting of $P$. radiata were used in this study (Table 2). The five best microsatellites for fingerprinting were selected based on reliability of amplification, observed heterozygosity, allele frequencies, and low frequency of null alleles (DEVEY et al., 2002). The standard PCR conditions were $20 \mathrm{ng}$ template DNA in a $15-\mu \mathrm{L}$ reaction consisting of $20 \mathrm{mM}$ Tris- $\mathrm{HCl}(\mathrm{pH} 8.4), 50 \mathrm{mM}$ $\mathrm{KCl}, 200 \mu \mathrm{M}$ of each dNTP, $3.0 \mathrm{mM} \mathrm{MgCl}_{2}, 0.27 \mu \mathrm{M}$ of each primer, and 0.5 U Taq DNA polymerase. PCR was performed on a Termo ELECTRON CORPORATION Termal Cycler PX2 thermocycler, and the standard temperature profile was $2 \mathrm{~min}$ at $94^{\circ} \mathrm{C}$ and 30 cycles of $10 \mathrm{~s}$ at $94^{\circ} \mathrm{C}, 30 \mathrm{~s}$ at $55^{\circ} \mathrm{C}, 30 \mathrm{~s}$ at $72^{\circ} \mathrm{C}$ and a final extension of $5 \mathrm{~min}$ at $72^{\circ} \mathrm{C}$. PCR products were visualized on silver-stained $6 \%$ poly-acrylamide denaturing gels. The

Table 1. - Origin of radiata pine investigated: geographical and climatic features of their zones of origin.

\begin{tabular}{|c|c|c|c|c|c|}
\hline \multirow{2}{*}{$\begin{array}{l}\text { Plus-trees origin } \\
\text { (site) }\end{array}$} & \multirow{2}{*}{$\begin{array}{c}\text { Anual } \\
\text { precipitation } \\
(\mathrm{mm})\end{array}$} & \multirow[b]{2}{*}{ Parent material } & \multicolumn{2}{|c|}{ Location } & \multirow{2}{*}{$\begin{array}{l}\text { Number of } \\
\text { individuals }\end{array}$} \\
\hline & & & $\begin{array}{c}\text { Latitude } \\
\text { S }\end{array}$ & $\begin{array}{l}\text { Longitude } \\
\text { W }\end{array}$ & \\
\hline $\begin{array}{l}\text { Eight Region } \\
\text { Sandy Soils }\end{array}$ & $1.100-1.208$ & Sandy & $37^{\circ} 31^{\prime}$ & $72^{\circ} 04^{\prime}$ & 9 \\
\hline $\begin{array}{l}\text { Seventh Region } \\
\text { Coastal }\end{array}$ & $450-950$ & $\begin{array}{c}\text { Granitic- } \\
\text { metamorphic }\end{array}$ & $35^{\circ} 21^{\prime}$ & $72^{\circ} 27^{\prime}$ & 11 \\
\hline $\begin{array}{c}\text { Eight Region } \\
\text { Coastal }\end{array}$ & 1.300 & $\begin{array}{l}\text { Granitic- } \\
\text { metamorphic }\end{array}$ & $38^{\circ} 14^{\prime}$ & $73^{\circ} 17^{\prime}$ & 14 \\
\hline $\begin{array}{l}\text { Other Areas of } \\
\text { the Eight Region }\end{array}$ & $1.000-1.600$ & $\begin{array}{c}\text { Sandy, Vocanic } \\
\text { ash }\end{array}$ & $\begin{array}{l}36^{\circ} 39^{\prime} \\
36^{\circ} 56^{\prime}\end{array}$ & $\begin{array}{l}71^{\circ} 40^{\prime} \\
72^{\circ} 22^{\prime}\end{array}$ & 6 \\
\hline
\end{tabular}




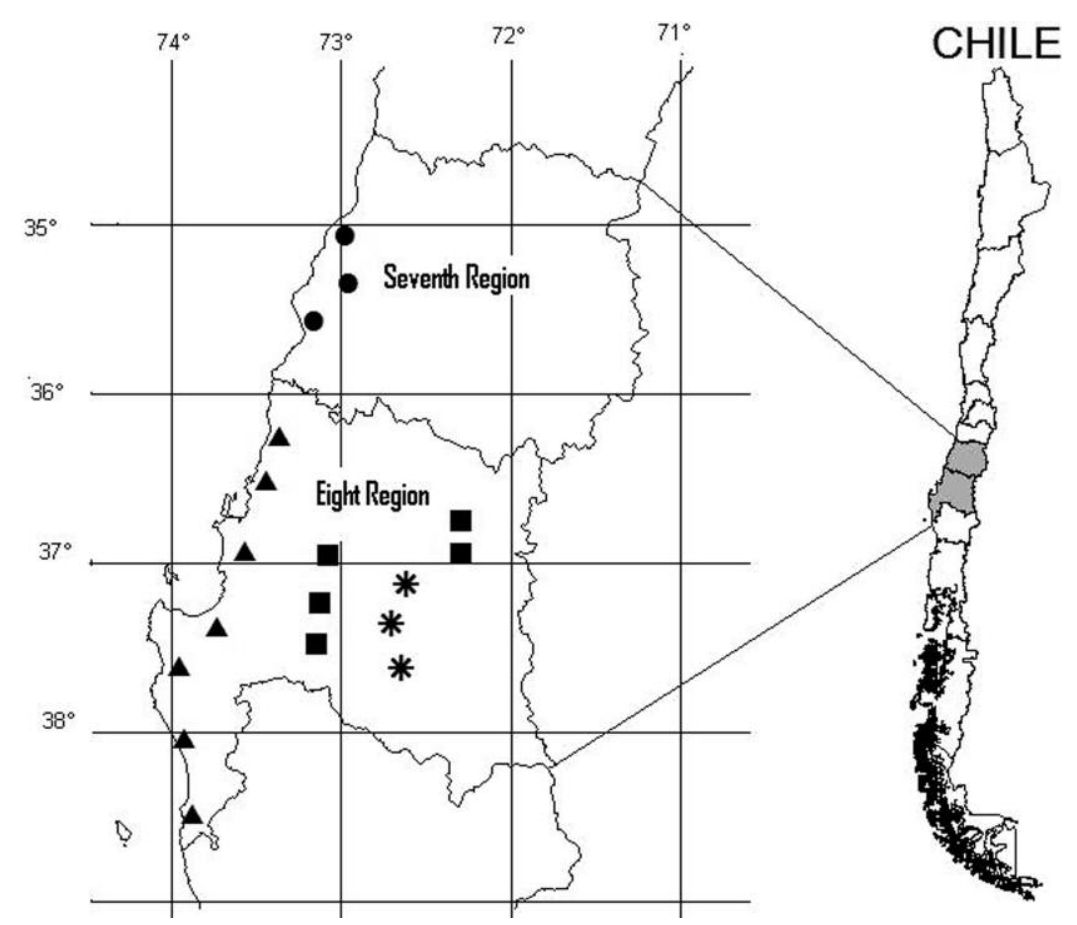

Figure 1. - Location of the radiata pine plus-trees collected between 1976-1978 (* = Sandy Soils Eight Region, $\bullet=$ Seventh Region Coast, $\boldsymbol{\Delta}=$ Eight Region Coast, $\mathbf{\square}=$ Other Areas of the Eight Region).

molecular weight marker pGem (Promega) was loaded for allele sizing.

\section{Within and between sites genetic variation}

To estimate the genetic diversity within and between sites of growth (i.e. plus-trees origin), the individuals of $P$. radiata were grouped according to Table 1 . Genetic parameters estimated for each site of growth included total genetic diversity $\left(\mathrm{H}_{\mathrm{T}}\right)$, the within sites diversity $\left(\mathrm{H}_{\mathrm{S}}\right)$, the between sites diversity $\left(\mathrm{F}_{\mathrm{ST}}\right)$, the proportion of total genetic diversity due to between-sites differences $\left(\mathrm{F}_{\mathrm{IS}}\right)$, the observed and expected heterozygosity $\left(\mathrm{H}_{\mathrm{O}}, \mathrm{H}_{\mathrm{E}}\right)$, the average and effective number of alleles per locus $(\mathrm{A}$,
Ae). With information from $\mathrm{H}_{\mathrm{O}}$ and $\mathrm{H}_{\mathrm{E}}$ for each loci at each site the presence or absence of Hardy Weinberg equilibrium was established. All parameters were calculated using the GENEPOP (YEH and Boyle, 1999) and Arlequin programs (EXCOFFIER et al., 2005).

\section{Structure analysis}

The structure of populations was assessed using the cluster algorithm included in the software STRUCTURE (PRITCHARD and WEN, 2003). Several different analyses assuming different number of clusters (K) were performed in order to assess how many of them explained best the data observed from microsatellites. The com-

Table 2. - Pinus radiata microsatellite markers for fingerprinting (DEVEY et al., 2002; BELL et al., 2004; KARHU et al., 2006).

\begin{tabular}{|c|c|c|c|c|}
\hline Locus & Repeat & $\begin{array}{c}\mathrm{N}^{\circ} \\
\text { alleles }\end{array}$ & $\begin{array}{l}\text { Size } \\
(\mathrm{pb})\end{array}$ & Primer sequences \\
\hline \multirow{2}{*}{$\operatorname{Pr} 284$} & \multirow{2}{*}{$(\mathrm{CT})_{14}$} & \multirow{2}{*}{$6-7$} & $97-113$ & CTTTGGATTCTCCCACAAGG \\
\hline & & & $104-120$ & CATGAGCACAATGAACACTAATAAATC \\
\hline \multirow{3}{*}{$\operatorname{Pr} 111$} & \multirow{3}{*}{$(\mathrm{CA})_{15}$} & \multirow{3}{*}{$8-10$} & $95-119$ & \\
\hline & & & $100-118$ & 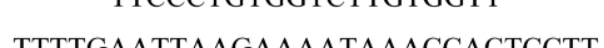 \\
\hline & & & $104-124$ & 1111GAA 1 1AAGAAAA \\
\hline \multirow{2}{*}{$\operatorname{Pr} 233$} & \multirow{2}{*}{$(\mathrm{CT})_{18}$} & \multirow{2}{*}{$15-21$} & $112-158$ & CATGACTTGACCTATGCACCTC \\
\hline & & & $118-160$ & GCATGCAAGAATGATGATGG \\
\hline \multirow{2}{*}{$\operatorname{Pr} 254$} & \multirow{2}{*}{$(\mathrm{CT})_{16}$} & \multirow{2}{*}{$9-10$} & $151-168$ & ACTTCAGCCTCTTCCTCACG \\
\hline & & & $152-172$ & GACCCGAAATTTTGTCTCCC \\
\hline \multirow{2}{*}{ Pr001 } & \multirow{2}{*}{$(\mathrm{CA})_{14}$} & \multirow{2}{*}{13} & $153-179$ & CAAAGATTACATTAATTCACTCCACC \\
\hline & & & $151-179$ & ATTCTTCСАТССАСТСТАTGAATG \\
\hline
\end{tabular}


parison between competing models (for a variable value of K) was assessed according to EvANO et al. (2005), manually inspecting the probabilities for the individuals in the populations, and using the log-likelihood values of the models assuming different $\mathrm{K}$.

\section{Results}

\section{Genetic diversity}

The measures of genetic diversity observed with five microsatellites in 40 unrelated individuals of the Chilean radiata pine plantations are presented in Table 3. All five loci genotyped were polymorphic and variable in all populations of radiata pine in Chile. Nine to 15 alleles per locus were detected, with a total of 57 alleles across all populations and loci (Table 3). Locus Pr001 had the highest number of alleles (15), in the range of 158-186 bp. Allele frequencies for each of the markers used are presented in Table 4 . The highest allele fre- quency was observed for Other Areas of the Eight Region, where the allele 126 of locus Pr233 reach a value of 0.42 , while the lowest frequency (i.e. 0.04) was found in several alleles for Pr001, Pr233 and Pr111 loci on site Eight Region Coast. Nineteen percent of the alleles found for the five loci were unique (i.e. alleles present on a site but absent in another), while $81 \%$ of the remaining alleles are common to all four sites. Three of the five loci had rare alleles (i.e. allele frequency less than 5\%), these were observed at Eight Region Coast. Sixty one percent of alleles were present at frequencies less than $25 \%$ and the remaining $(28 \%)$ were present at frequencies less than $42 \%$. The distribution of alleles at some loci results in greater genetic discrimination than at others. For instance Pr001 has 15 alleles, but none at a frequency greater than $25 \%$ for the four sites, whereas Pr111 has only 9 alleles, but just one (i.e., allele 115) contributed greater than $25 \%$ of total frequency in the four sites.

Table 3. - Genetic diversity measures for 40 half-sib individuals of Radiata pine.

\begin{tabular}{cccccccc}
\hline LOCUS & $\mathrm{A}$ & $\mathrm{Ae}$ & $\begin{array}{c}\text { Smallest } \\
(\mathrm{bp})\end{array}$ & $\begin{array}{c}\text { Largest } \\
(\mathrm{bp})\end{array}$ & $\begin{array}{c}\mathrm{He} \\
( \pm \mathrm{SE})\end{array}$ & $\begin{array}{c}\text { Ho } \\
( \pm \mathrm{SE})\end{array}$ & $\mathrm{F}_{\mathrm{ST}}$ \\
\hline Pr001 & 15 & 10.53 & 158 & 186 & $0.92 \pm 0.01$ & $0.80 \pm 0.01$ & 0.03 \\
Pr111 & 9 & 4.98 & 107 & 127 & $0.81 \pm 0.02$ & $0.78 \pm 0.03$ & 0.02 \\
$\operatorname{Pr} 233$ & 14 & 7.80 & 118 & 146 & $0.91 \pm 0.05$ & $0.86 \pm 0.02$ & 0.07 \\
$\operatorname{Pr} 254$ & 9 & 6.58 & 152 & 156 & $0.86 \pm 0.05$ & $0.89 \pm 0.02$ & 0.06 \\
$\operatorname{Pr} 284$ & 10 & 6.19 & 102 & 118 & $0.87 \pm 0.03$ & $0.80 \pm 0.02$ & 0.05 \\
\hline Overall & 11.4 & 7.2 & & & $0.87 \pm 0.03$ & $0.83 \pm 0.06$ & 0.04
\end{tabular}

Table 4. - Allele sizes and frequencies at five microsatellite marker loci in 40 Radiata pine individuals belonging to four sites in Central Chile.

\begin{tabular}{|c|c|c|c|c|c|c|c|c|c|c|c|c|c|c|c|c|c|c|c|c|c|c|c|c|}
\hline \multirow{3}{*}{$\begin{array}{l}\text { Locus } \\
\text { Pr001 } \\
\text { Alleles }\end{array}$} & & & & & \multirow{3}{*}{$\begin{array}{l}\text { Locus } \\
\text { Pr111 } \\
\text { Alleles }\end{array}$} & & & & & \multirow{3}{*}{$\begin{array}{l}\text { Locus } \\
\text { Pr233 } \\
\text { Alleles }\end{array}$} & \multirow[b]{3}{*}{ A8 } & \multirow{2}{*}{\multicolumn{3}{|c|}{ Allele frequency }} & \multirow{3}{*}{$\begin{array}{l}\text { Locus } \\
\text { Pr254 } \\
\text { Alleles }\end{array}$} & \multirow{3}{*}{\multicolumn{5}{|c|}{$\begin{array}{l}\text { Locus } \\
\text { Pr284 } \\
\text { Alleles }\end{array}$}} & \multirow{2}{*}{\multicolumn{4}{|c|}{ Allele frequency }} \\
\hline & \multicolumn{4}{|c|}{ Allele frequency } & & \multicolumn{4}{|c|}{ Allele frequency } & & & & & & & & & & & & & & & \\
\hline & A8 & $\mathrm{C} 7$ & C8 & OA8 & & A8 & $\mathrm{C} 7$ & $\mathrm{C} 8$ & OA8 & & & C7 & $\mathrm{C} 8$ & OA8 & & & & & & & A8 & C7 & $\mathrm{C} 8$ & OA8 \\
\hline 158 & & 0.09 & & & 107 & & 0.05 & 0.04 & 0.08 & 118 & & 0.05 & 0.04 & & 152 & & 0.05 & & & 102 & & 0.25 & 0.08 & 0.33 \\
\hline 160 & 0.06 & & & & 109 & 0.06 & 0.09 & 0.18 & & 120 & & 0.05 & & 0.17 & 154 & & 0.05 & & & 104 & 0.06 & & & \\
\hline 162 & 0.13 & 0.09 & 0.21 & 0.08 & 111 & 0.06 & & 0.04 & 0.33 & 122 & 0.17 & & 0.14 & 0.08 & 156 & & 0.18 & 0.07 & & 106 & 0.17 & 0.31 & 0.21 & 0.33 \\
\hline 164 & 0.13 & 0.09 & 0.04 & 0.08 & 115 & 0.39 & 0.32 & 0.29 & 0.08 & 124 & 0.11 & 0.20 & 0.18 & & 158 & 0.06 & 0.09 & 0.25 & 0.33 & 108 & 0.22 & 0.25 & 0.25 & 0.08 \\
\hline 166 & 0.06 & 0.14 & 0.13 & & 117 & 0.11 & 0.14 & 0.11 & 0.33 & 126 & 0.33 & & 0.11 & 0.42 & 160 & 0.39 & 0.18 & 0.18 & 0.33 & 110 & 0.11 & & 0.17 & \\
\hline 168 & & 0.14 & 0.17 & 0.25 & 119 & 0.28 & 0.14 & 0.18 & 0.17 & 128 & 0.06 & 0.20 & 0.11 & & 162 & 0.11 & 0.09 & 0.29 & 0.08 & 114 & 0.06 & 0.06 & & 0.17 \\
\hline 170 & 0.13 & 0.14 & 0.08 & 0.25 & 121 & 0.06 & 0.23 & 0.14 & & 130 & 0.06 & & & 0.17 & 164 & & 0.14 & 0.14 & 0.17 & 116 & & & & 0.08 \\
\hline 172 & & 0.05 & 0.04 & 0.08 & 123 & 0.06 & & 0.04 & & 132 & & 0.10 & 0.07 & 0.17 & 166 & 0.39 & 0.09 & & & 118 & 0.22 & & 0.13 & \\
\hline 174 & 0.13 & & 0.08 & 0.08 & 127 & & 0.05 & & & 134 & & 0.05 & 0.11 & & 168 & 0.06 & 0.14 & 0.07 & 0.08 & 120 & 0.17 & 0.13 & 0.08 & \\
\hline 176 & & 0.09 & 0.08 & & & & & & & 136 & 0.06 & 0.10 & 0.04 & & & & & & & 122 & & & 0.08 & \\
\hline 178 & 0.06 & & & 0.08 & & & & & & 138 & 0.17 & 0.05 & 0.18 & & & & & & & & & & & \\
\hline 182 & 0.06 & & 0.04 & & & & & & & 142 & & 0.10 & 0.04 & & & & & & & & & & & \\
\hline 184 & 0.06 & 0.05 & & & & & & & & 146 & & 0.10 & & & & & & & & & & & & \\
\hline 186 & 0.19 & 0.09 & 0.08 & 0.08 & & & & & & 148 & 0.06 & & & & & & & & & & & & & \\
\hline 188 & & 0.05 & 0.04 & & & & & & & & & & & & & & & & & & & & & \\
\hline
\end{tabular}

A8 = Sandy Soils Eight Region, C7 = Seventh Region Coast, C8 = Eight Region Coast, OA8 = Other Areas of the Eight Region. 
On the other hand, the pattern of allelic diversity calculated for each site indicated that the families on site Other Areas of the Eight Region had the lowest number of alleles (mean $=5.6$ ), compared to Coastal Sites of the Eight and Seventh Regions and the Eight Region Sandy Soils Sites (i.e. average of 8.4, 8.4 and 8.0 alleles, respectively). Effective number of alleles per locus ranged from five to eleven. Observed heterozygosity $\left(\mathrm{H}_{\mathrm{O}}\right)$ ranged from 0.78 to 0.89 with an average of 0.83 . Expected heterozygosity $\left(\mathrm{H}_{\mathrm{E}}\right)$ ranged from 0.81 to 0.92 with an average of 0.87. Table 3 shows the number of alleles, effective number of alleles, allele size, expected and observed heterozygosity for each microsatellite. In the four sites tested no deviation with regard to the proportions expected under Hardy-Weinberg equilibrium (data not shown) was observed.

\section{Within and between sites genetic variation}

In assessing the F-statistics between growth zones it was found that the total genetic diversity was $0.87\left(\mathrm{H}_{\mathrm{T}}\right)$. The average inbreeding coefficients (corresponding to $\mathrm{F}_{\mathrm{IS}}$ ) was about 0.04 , the within-sites diversity was high $\left(\mathrm{H}_{\mathrm{S}}=0.82\right)$, while the genetic differentiation between sites was low $\left(\mathrm{F}_{\mathrm{ST}}=0.04\right)$ (Table 3).

\section{Structure analysis}

The structure analysis showed two clusters $(\mathrm{K}=2)$ as the best choice for explaining the observed variability when using the Evano method. However one of the flaws of this method is that it is undefined for $\mathrm{K}=1$. Inspecting the posterior probabilities of clusters for each individual in the populations reveal that everyone of them show nearly equal probabilities of belonging to each of the two clusters. Inspecting the $\log \operatorname{Prob}(\mathrm{X} \mid \mathrm{K})$ reveal that for $K=1$ the mean log-likelihood was equal to $-849.3(\mathrm{SD}=0.74)$ whereas for $\mathrm{K}=2$ was equal to -852.0 ( $\mathrm{SD}=3.71)$. These results suggest that a single cluster best explained the data.

\section{Discussion}

As far as we know this is the first study looking at genetic diversity of Chilean $P$. radiata plantations using microsatellite markers. An earlier publication characterized genetic diversity in Chilean families of $P$. radiata, and showed that they had a high level of variation (CAMPOS, 2001), however, and despite 100 RAPDs primers were analyzed, only four families were used to represent the Chilean plantations. Individuals used in our study represents the current geographical distribution of this species in Chile (see Figure 1), so that, the current genetic base of breeding programs for $P$. radiata in Chile is clear.

With microsatellite loci the estimated level of genetic diversity in the base breeding population of radiata pine in Chile is more than eight times that from isozyme loci (MORAN and BELL, 1987). As was mentioned before, one of the characteristics to select the five microsatellites developed by DEver et al. (2002) was the absence of null alleles. In our study, all five markers were in HardyWeinberg equilibrium and only 17 homozygotes were found between all the 400 genotypes analyzed (data no shown), so there is indeed a low probability of nulls alleles in the populations analyzed. Although radiata pine has been traditionally considered to have low levels of diversity (MoRAN et al., 1988; DEvEY et al., 2002; BELL et al., 2004; KARKU et al., 2006), values of genetic diversity reported here are superior to those found in annual plants, herbaceous perennials and woody perennials (i.e. $\mathrm{H}_{\mathrm{E}}=0.09-0.14, \mathrm{~A}=1.45-1.74$ ) (HAMRICK et al., 2002), which means that pines are among the most genetically variable of all species. In the case of $P$. radiata, native populations of Guadalupe Island, despite having less than 400 trees in total, it maintain diversity levels similar to those found in Cambria, Monterrey and Año Nuevo populations, with over 1,000,000 trees (MoRAN et al., 1988; ROGERS, 2002; KARHU et al., 2006; RoGERS et al., 2006), which confirms high genetic diversity levels of the species.

Microsatellite markers allow this study to estimate the genetic diversity in the Chilean plantations of $P$. radiata and, despite the limited number of individuals and loci analyzed, coherent results were obtained with those reported by breeding programs of $P$. radiata in Australia (DEVEY et al., 2002; BELL et al., 2004) and in native populations (KARKU et al., 2006). Analysis of microsatellite variation in native $P$. radiata populations reveals that $\mathrm{H}_{\mathrm{E}}$ was in the 0.68-0.77 range, $\mathrm{A}$ between $6.7-10$ and $\mathrm{F}_{\mathrm{ST}}$ between 0.06-0.22 (KARKU et al., 2006), while for Chilean plantations, values reported here were $\mathrm{H}_{\mathrm{E}}=0.81-0.92, \mathrm{~A}=9-15$ and $\mathrm{F}_{\mathrm{ST}}=0.02-0.07$ (Table 3), indicating that in the process of introduction and subsequent adaptation to local conditions in Chile, $P$. radiata has retained levels of genetic diversity similar to those of the natural populations of the species. This suggests that in Chile the 1890 P. radiata introduction contained a high proportion of genetic diversity registered in natural populations. According to CAMUs (2006), in 1891 20,000 plants of $P$. radiata were planted in the Eighth Region, which clearly contained a high genetic diversity that was conserved during the process of introduction and subsequent domestication to become a landrace. Results from the structure analysis suggests that for $\mathrm{K}=2$ the clustering was more uncertain. For these reasons, we estimate that the most likely number of clusters appearing in the population was equal to 1 , which is in line to what is expected from introductions records of $P$. radiata in Chile. There was one major source of original importation registered at about 1890 (CAMUS, 2006), and despite there is no information about the native provenance from where the seed come from, this was sufficient to provide the genetic variation successfully utilized for the economically significant genetic gain achieved in $30 \mathrm{y}$ of breeding. In Australia, second generation clones of breeding programs maintained genetic diversity similar to the natural populations (BELL et al., 2004). This allows to speculate that advanced generations families in Chilean breeding programs maintain genetic diversity levels similar to those reported in this study (individuals used in this study had not been selected for breeding purposes yet). On the other hand, in Australia and New Zealand, the genetic base of the present plantations has been shown to be from only Año Nuevo and Monterey, the two best-adapted of the five 
natural populations (MORAN and BELL, 1987; BURDON, 1992). This could be explained because two large importations of seed were registered (Wu et al., 2007). The earliest records show radiata pine was first introduced in Australia in 1857, and twenty years later, a second consignment (i.e. $11 \mathrm{~kg}$ in 1876), arrive to the country and probably came from a large number of trees.

The population demography of radiata pine is quite different from many other pines. Early genetic studies of natural populations of $P$. radiata using protein electrophoresis (MoRAN et al., 1988) have shown that overall genetic diversity in this species is lower than in many other conifers $\left(\mathrm{H}_{\mathrm{T}}=0.11\right)$ and genetic differentiation between populations is higher $\left(\mathrm{F}_{\mathrm{ST}}=0.16\right)$. Usually the proportion of total genetic diversity found among populations of wind-pollinated conifers is less than $10 \%$ and often less than $5 \%$ (LEDIG, 1998), which means that over $90 \%$ of the total variation is within populations. In this study, $83 \%$ of the variation was found within the four analyzed sites $\left(\mathrm{H}_{\mathrm{S}}\right)$. We reported an overall $\mathrm{F}_{\mathrm{ST}}$ value of 0.04 , which indicates that $4 \%$ of the genetic variation present in radiata pine in Chile is partitioned among sites, indicating they are poorly differentiated. Most forest tree species have estimated $\mathrm{F}_{\mathrm{ST}}$ between 0.01 to 0.17 (DELGADO et al., 2002), which suggests extensive gene flow (SLAVOv et al., 2004). This pattern of genetic structure is common in conifers with large distributional ranges (e.g., GAPARE et al., 2005) and it is in agreement with other studies that used molecular markers for radiata pine (ARREGUI et al., 1999; VoGL et al., 2002) and other conifers (HAMRICK et al., 1992).

The level of microevolutionary divergence among populations is influenced by the opposite effects of migration, which tends to homogenize the population, and genetic drift or mutation, which leads to differentiation of populations (HARTL and CLARK 1989; WHITE et al., 2007). In this sense, it can be argued that since the introduction of $P$. radiata in Chile in the Eight Region (i.e. city of Concepción) there was a high seed movement into other growth areas of central Chile, given the rapid growth of the species, the low intensity of selection and low restriction to seed transfer between different areas (CAMUS, 2006). This could have possibly increased gene flow and contributed to the maintenance of genetic diversity and low differentiation among sites. In addition, it is likely that the intensity of natural selection experienced in the first generations after planting in 1891, has been low and has not altered allele frequencies, since it was introduced in a coastal area with soil and climatic characteristics similar to the species' natural range (i.e. Eighth Region Coastal Sites) (BURNS and Honkala, 1990; SANTIBAÑEZ and URIBE, 1993; GERDING and Schlatter, 1995; Flores and Allen, 2004; Huber and TRECAMAN, 2004). One way plants will respond to changes in environmental conditions is through environmentally induced shifts in phenotype, i.e. phenotypic plasticity (the ability of a genotype to alter its morphology and physiology in response to changes in the environmental conditions) (BRADSHAW, 1965; SCHLICHTING, 1986; Sultan, 1987; Nicotra et al., 2010), which allows species to grow in a range of environments (CORCUERA et al., 2010). EsPINOZA (2012) found that $P$. radiata planta- tions in Chile, despite a lack of neutral genetic divergence, show evidence of local adaptation. Given the history of its introduction in Chile and the rapid expansion following introduction, once established in new environments, new Radiata pine plantations experienced different selection pressures, resulting in adaptation to new conditions.

\section{Acknowledgments}

This work was achieved during the first author's $\mathrm{Ph}$. D. thesis work in the Universidad de Chile. We gratefully acknowledge Forestal Celco S.A. and Forestal Mininco S.A. for supplying the seeds to carry out the experiment. Financial support was granted by Innova Chile (Contract $\mathrm{N}^{\circ}$ 06FC01 IXC-96). Many thanks to Dr. Rómulo SANTElices, Director of the Centro de Desarrollo para el Secano Interior for supporting this research, and also to CARMEN BRAVO, Director of the Departamento de Ciencias Forestales at Universidad Católica del Maule, for providing facilities and support in laboratory work.

\section{References}

ADAms, W. (1981): Population genetics and gene conservation in Pacific Northwest conifers, pp. 401-415. In: Evolution Today, Proc $2^{\text {nd }}$ Int Cong Syst Evol Biol, edited by C. G. E. Scudder and J. L. Reveal. Hunt Inst Bot Document, Pittsburgh.

Ades, P. K. and J. A. Simpson (1991): Variation in susceptibility to Dothistroma needle blight among provenances of Pinus radiata var. radiata. Silvae Genet. 40: 6-13.

Allendorf, F. W. and R. F. LEARY (1986): Heterozygosity and fitness in natural populations of animals, pp. 57-76. In: Conservation Biology, edited by M.E. SoulÉ, Sinauer. Sunderland/MA.

Aragones, A., I. Barrena, S. Espinel, A. Herran and E. RITTER (1997): Origin of Basque populations of Radiata pine from RAPD data. Ann. Sci. For. 54: 697-703.

Arregui, A., S. Espinel, A. Aragones and R. Sierra (1999): Estimación de parámetros genéticos en un ensayo de progenie de Pinus radiata D. Don en el país Vasco. Invest. Agr. Sist. Recur. For. 8 (1): 119-128.

AXELROD, D. I. (1980): History of maritime closed-cone pines, Alta and Baja California. University of California Press, California, USA.

Bell, J., M. Powell, M. Devey and G. Moran (2004): DNA Profiling, Pedigree Lineage Analysis and Monitoring in the Australian Breeding Program of Radiata Pine. Silvae Genet. 53 (3): 130-134.

BRADSHAW, A. D. (1965): Evolutionary significance of phenotypic plasticity in plants. Advances in Genetics. 13: $115-155$.

BuRDON, R. D. (1978): Mejoramiento genético forestal en Chile. CONAF-FAO. FO.DP/CHI/76/003. Documento de Trabajo $\mathrm{N}^{\circ} 11,81 \mathrm{pp}$.

Burdon, R. D., M. H. Bannister and C. A. Low (1992): Genetic survey of Pinus radiata. 2: Population comparisons for growth rate, disease resistance, and morphology. N. Z. J. For. Sci. 22: 138-159.

Burns, R. and B. Honkala (1990): Conifers, pp. 1-1383. In: Silvics of North America. Agriculture Handbook. U.S. Department of Agriculture, Forest Service, Washington, DC. 
CAmus, P. (2006): Ambiente, bosques y gestión forestal en Chile 1541-2005. Santiago, Chile. Diban LOM.

Campos, H., B. Soto and C. Venegas (2001): Genetic analysis of Monterrey pine (Pinus radiata) breeding families with RAPD genetic markers. In: Proceedings from IV Encuentro Latinoamericano de Biotecnología Vegetal, 4-8 June 2001, Goiania, Brasil.

Corcuera, L., E. Gil-Pelegrin and E. Notivol (2010): Phenotypic plasticity in Pinus pinaster $\delta^{13} \mathrm{C}$ : environment modulates genetic variation. Annals of Forest Science. 67: 812 .

Delgado P., A. Cuenza, A. E. Escalante, F. MolinaFreANER and D. PiÑERo (2002): Comparative genetic structure in pines: evolutionary and conservation consequences. Rev. Chil. Hist. Nat. 75: 27-37.

Devey, M., J. Bell, T. Uren and G. Moran (2002): A set of microsatellite markers for fingerprinting and breeding applications in Pinus radiata. Genome. 45: 984-989.

Ennos, R. A., N. R. Cowie, C. J. LegG and C. Sydes (1997): Which measures of genetic variation are relevant in plant conservation? A case study of Primula scotica, pp. 73-79. In: The Role of Genetics in Conserving Small Populations, edited by T. J. CRAWFORD, J. Spenser, D. Stevens, M. B. Usher, T. E. Tew and J. WARREN. JNCC, Peterborough.

EsPINOZA, S. (2012): Caracterización de la raza local de Pinus radiata D. Don en Chile en relación a su diversidad genética y respuesta temprana frente a una restricción hídrica. Tesis Doctoral. Universidad de Chile. $115 \mathrm{p}$.

Evano, G., S. Regnaut and J. Goudet (2005): Detecting the number of clusters of individuals using the software STRUCTURE: a simulation study. Molecular Ecology. 14: $2611-2620$.

Excoffier, L. G. and S. SchneIder (2005): Arlequin ver. 3.0: An integrated software package for population genetics data analysis. Evol. Bioinform. 1: 47-50.

Flores, F. and H. Allen (2004): Efectos del clima y capacidad de almacenamiento de agua del suelo en la productividad de rodales de pino radiata en Chile: un análisis utilizando el modelo 3-PG. Bosque 25 (3): 11-24.

Fundación Chile (2005): Simulador de árbol individual para pino radiata (Pinus radiata D. Don): Arquitectura de Copa y Calidad de Madera. Manual Práctico de Manejo. Proyecto FONDEF D01/1021. 126 pp.

Frankel, O. H. (1983): The place of management in conservation, pp. 1-14. In: Genetics and Conservation, edited by C.M. Schonewald-Cox, S.M. Chambers, B. MacBryde and L. Thomas. Benjamin-Cummings, Menlo Park, California, USA.

GAPARE, W. J., S. N. AitKen and C. E. Ritland (2005): Genetic diversity of core and peripheral Sitka spruce (Picea sitchensis (Bong.) Carr) populations: implications for conservation of widespread species. Biol Conser. 123: $113-123$.

Gapare, W. J., B. S. Baltunis, M. Ivković, C. B. Low, P. JEFFERSON and H. X. Wu (2011): Performance differences among ex-situ native-provenance collections of Pinus radiata D. Don. 1: Potential for infusion into breeding populations in Australia and New Zealand. Tree Genet. Genomes. 7: 409-419.

GEBUREK, T. (1997): Isozymes and DNA markers in gene conservation of forest trees. Biodiversity and Conservation. 6: 1639-1654.

Hamrick, J. L., M. J. W. Godt and S. L. Sherman-Broyles (1992): Factors influencing levels of genetic diversity in woody plant species. New. For. 6: 95-124.
HAMRICK, J. L. (2004): Response of forest trees to global environmental changes. For. Ecol. Manag. 197: 323-335.

HART, D. L. and A. G. Clark (1989): Principles of population genetics. Sinauer Associates Inc., Sunderland, Massachusetts.

Huber, A. and R. TRecaman (2004): Eficiencia del uso del agua en plantaciones de Pinus radiata en Chile. Bosque 25 (3): 33-43.

INFOR. (2010): Anuario Forestal 2010. Instituto Forestal, Chile. Boletín Estadístico $\mathrm{N}^{\circ}$ 128. 134 pp.

Johnson, I. G., P. K. AdEs and K. G. EldRIDGe (1997): Growth of natural Californian provenances of Pinus radiata in New South Wales, Australia. N. Z. J. For. Sci. 27: 23-38.

Karhu, A., C. Vogl, G. Moran, J. Bell and O. Savolainen (2006): Analysis of microsatellite variation in Pinus radiata revelas effect of genetic drift but no recent bottlenecks. J. Evol. Biol. 19: 167-175.

LEDIG, F. T. (1998): Genetic variation in Pinus, pp. 251-280. In: Ecology and biogeography of Pinus, edited by D. M. RICHARDSON. Cambridge University Press, Cambridge, U.K.

Lewis, N. B. and I. S. Ferguson (1993): Management of radiata pine. Melbourne, Australia. Inkata Press.

Matheson, A. C., K. G. Eldridge, A. G. Brown and D. J. Spender.(1986): Wood volume gains from first-generation radiata pine seed orchards. DFR User Series, No. 4, Forest Research, CSIRO, Canberra.

Moran, G. and J. Bell (1987): The origin and genetic diversity of Pinus radiata in Australia. Theor. Appl. Genet. 73: 616-622.

MorAn, G., J. BeLl and K. EldRIDGe (1988): The genetic structure and the conservation of the five natural populations of Pinus radiata. Can. J. For. Res. 18: 506-514.

Muñoz, M. (2008): Silvicultura de Pinus radiata D. Don. Talca-Chile. Editorial Universidad de Talca. Colección Académica.

Nicotra, A. B., O. K. Atkin, S. P. Bonser, A. M. Davidson, E. J. Finnegan, U. Mathesius, P. Рoot, M. D. PurugGanan, C. L. Richards, F. VAlladares and M. VAN KLEUNEN (2010): Plant phenotypic plasticity in a changing climate. Trends in Plant Science. 15: 684-692.

Petit, R. and A. HAMPE (2006): Some evolutionary consequences of being a tree. Annu. Rev. Ecol. Evol. S. 37: 187-214.

PRITChARD, J. K. and W. Wen (2003): Documentation for STRUCTURE software:Version 2. Available from http://pritch.bsd.uchicago.edu.

ROGERS, D. (2002): In situ genetic conservation of Monterey pine (Pinus radiata D. Don). Information and recommendations. University of California, Division of Agriculture and Natural Resources, Genetic Resources Conservation Program Report No. 26. Davis, California, USA.

Rogers, D., C. Matheson, J. J. Vargas-Hernandez and J. J. GuERRA-SANTOS (2006): Genetic conservation of insular populations of monterey pine (Pinus radiata D. Don). Biodivers. Conserv. 15: 779-798.

SANTIBAÑEZ, F. and J. URIBE (1993): Atlas agroclimático de Chile. VI, VII, VIII y IX Regiones. Santiago: Laboratorio de Agroclimatología, Facultad de Ciencias Agrarias y Forestales, Universidad de Chile, 1993, 73 pp.

Schlichting, C. D. and M. Pigliucci (1998): Phenotypic evolution - A reaction norm perspective. Sinauer Associates, Sunderland, MA. 